\title{
Monitoring of Phytoplankton Abundance and Chlorophyll-a Content in the Estuary of Banjar Kemuning River, Sidoarjo Regency, East Java
}

\author{
Nabila Zahro Al Diana ${ }^{1}$, Luthfiana Aprilianita Sari ${ }^{2 *}$, Sulastri Arsad ${ }^{3}$, \\ Kustiawan Tri Pursetyo ${ }^{4}$, Yudi Cahyoko²
}

1 Aquaculture Study Program, Faculty of Fisheries and Marine, Universitas Airlangga, Surabaya 60115, Indonesia

2 Department of Fish Health Management and Aquaculture, Faculty of Fisheries and Marine, Universitas Airlangga, Surabaya 60115, Indonesia

3 Department of Aquatic Resources Management, Faculty of Fisheries and Marine Science, Universitas Brawijaya, Jl. Veteran Malang 65145, Indonesia

${ }^{4}$ Faculty of Fisheries and Food Science, Universiti Malaysia Terengganu, 21030 Kuala Nerus, Terengganu, Malaysia

*Corresponding author's e-mail: luthfianaas@fpk.unair.ac.id

\begin{abstract}
Estuaries are coastal areas that have a fairly high fertility rate. This region can be said to be fertile because it is influenced by such physical factors as temperature, turbidity, light, and current as well as such chemical factors as salinity, dissolved oxygen, $\mathrm{pH}$, and nutrient content. The estuary of the Banjar Kemuning River is a coastal area with a lot of human activities, and it is close to the mainland, causing the change in the nutrient content in the waters. The nutrient content in the waters is closely related to the phytoplankton abundance, as the higher the nutrient content in the waters, the greater the phytoplankton abundance and the chlorophyll-a content. The level of chlorophyll-a content in the waters can indirectly be used as an indicator of the phytoplankton abundance, which can determine the level of fertility of these waters. The purpose of this study was to determine the relationship between the phytoplankton abundance and the chlorophyll-a content in the estuary of the Banjar Kemuning River. This study is observational research with data analysis using linear regression, simple correlation (Pearson), and ANOVA. In addition, the data collection was carried out by purposive random sampling at predetermined points of stations. The results of this study indicated that the phytoplankton abundance and the chlorophyll-a content at the estuary of Banjar Kemuning River during different months were significantly different $(\mathrm{P}<0.05)$. The average phytoplankton abundance during the study was 19,256 cells/L, 19,044 cells/L, and 22,613 cells/L, while the average chlorophyll-a content during the study was $0.958 \mu \mathrm{g} / \mathrm{L}, 0.998 \mu \mathrm{g} / \mathrm{L}$, and $1.167 \mu \mathrm{g} / \mathrm{L}$. The conclusion was drawn that there is a difference between the phytoplankton abundance and the chlorophyll-a content each month and classified into high correlation.
\end{abstract}

Keywords: marine, blue water, ecological footprint, pollution, water quality

\section{INTRODUCTION}

The coastal areas that have a fairly high fertility rate are called estuaries. The areas include estuaries and large deltas, mangrove forests near estuaries, and extensive sand dune (Sari et al., 2019a; Sari et al., 2019b; Sari et al., 2018a). This region can be said to be fertile because it is influenced by physical factors which include temperature, turbidity, light and current as well as chemical factors in the environment including salinity, dissolved oxygen, $\mathrm{pH}$ and nutrient content (Mellard et al., 2011; Putri et al., 2018; Syaifudin 2017). These factors can affect the growth of 
phytoplankton and zooplankton in the waters. A high level of phytoplankton growth can increase the abundance of phytoplankton in the waters (Pratiwi et al., 2015). The estuary of the Banjar Kemuning River is an area that is rich in nutrient content, so the nutrient content can be said to fertilize the coastal areas (Sari et al., 2018b; Suprapto et al., 2014). The nutrient content in the estuaries can increase the growth of phytoplankton (Rinawati et al., 2020; Pratama et al., 2020). Specifically, the content of nutrients such as nitrogen and phosphorus can be said to be the main requirements for the phytoplankton life (Azmi et al., 2020; Masithah et al., 2016).

The nutrient content in estuaries is used by phytoplankton to grow and develop (Wenno, 2007). The nutrient content in the waters is closely related to the phytoplankton abundance, as the higher the nutrient content in the waters, the greater the phytoplankton abundance and the chlorophyll-a content. Magumba et al. (2013) stated that the nitrogen element is very siginificant to the chlorophyll content, especially chlorophyll-a, which is the type of chlorophyll that is mostly found in seawater phytoplankton (Arief \& Laksmi, 2006), and chlorophyll-a contributes $95 \%$ to primary productivity in the sea (Widyorini, 2009).

According to Valiela (1984), the content distribution of chlorophyll is higher in the sea and coastal areas, but it is lower in offshore waters. It is caused by the presence of large amount of nutrient supply through the run-off from the mainland, while the low chlorophyll content in offshore waters is due to the absence of direct nutrient supply from the mainland. The level of the chlorophyll-a content in the waters can be indirectly used as an indicator of the phytoplankton abundance, which can determine the level of fertility of these waters. The fertility of waters is very important, so it is necessary to conduct research on the analysis of the phytoplankton abundance and the chlorophyll-a content in the estuary of Banjar Kemuning River, Sedati District.

\section{MATERIAL AND METHODS}

This research was conducted from October to December, when there was a seasonal change from the dry to the rainy season at $09.00-11.00$ GMT +7 with plankton nets $(20 \mu \mathrm{m}$ mesh size $)$. This study is a type of observational research using a quantitative descriptive method with analyzed using Analysis of Variance (ANOVA), followed by Duncan's Multiple Range Test, simple correlation analysis (Pearson) and regression analysis (Nindarwi et al., 2020; Liyana et al., 2019; Sugiyono, 2004).

The sampling site was divided into two zones, namely zone A which was the estuary of Banjar Kemuning River, and zone B that separated the estuary and the open area. Zone A consisted of three stations, namely A1, A2, and A3. The first station (A1) was close to the residential areas, while the second station (A2) was close to ponds, and the third station (A3) was close to mangrove forests. Meanwhile, zone B consisted of three stations, namely B1, B2, and B3 facing the open area. The first station (B1) was closer to the estuary, while the second station (B2) was between the first and the third stations, and the third station (B3) itself was in the open area. The map of the sampling site can be seen in Figure 1.

The water samples were collected using a plankton net with a diameter of $20 \mathrm{~cm}$ as far as 3 meters with a distance of 200 meters from each station. The water bottles used for sampling had to be dark so that the chlorophyll content contained by phytoplankton was not easily damaged. Furthermore, the sample bottles were stored in a coolbox and given an ice cube after arriving on land; the temperature in the coolbox was $\pm 4^{\circ} \mathrm{C}$ (Marlian, 2016; Larasati, 2017). The environmental parameters were recorded from each station. Salinity was measured using a refractometer [ATAGO]. The measurement of $\mathrm{pH}$ used a $\mathrm{pH}$ meter [HANNA]. The measurement of dissolved oxygen and temperature used a DO meter [YSI $550 \mathrm{~A}]$. The measurement of turbidity at each station used a Secci disc. Ammonia (Indonesian National Standard (SNI) 6-6989.30.2005), nitrate (SNI 6989.79. 2011), nitrite (SNI 6989.79:2011) and phosphate (SNI 06-6989.31. 2005) are tested in the of Institute for Research and Standardization of Industry (BARISTAND), Surabaya. The measurement of the chlorophyll-a content was carried out at the Laboratory of Chemistry and Analysis at the Faculty of Fisheries and Marine Sciences using the spectrophotometric method (Vonshak, 1997).

The sample identification was carried out using the $1 \mathrm{~mL}$ sub-sample method (Arinardi et al., 1997). The identification process was carried out on a glass object using a microscope magnification of $100-400$ times. The plankton 


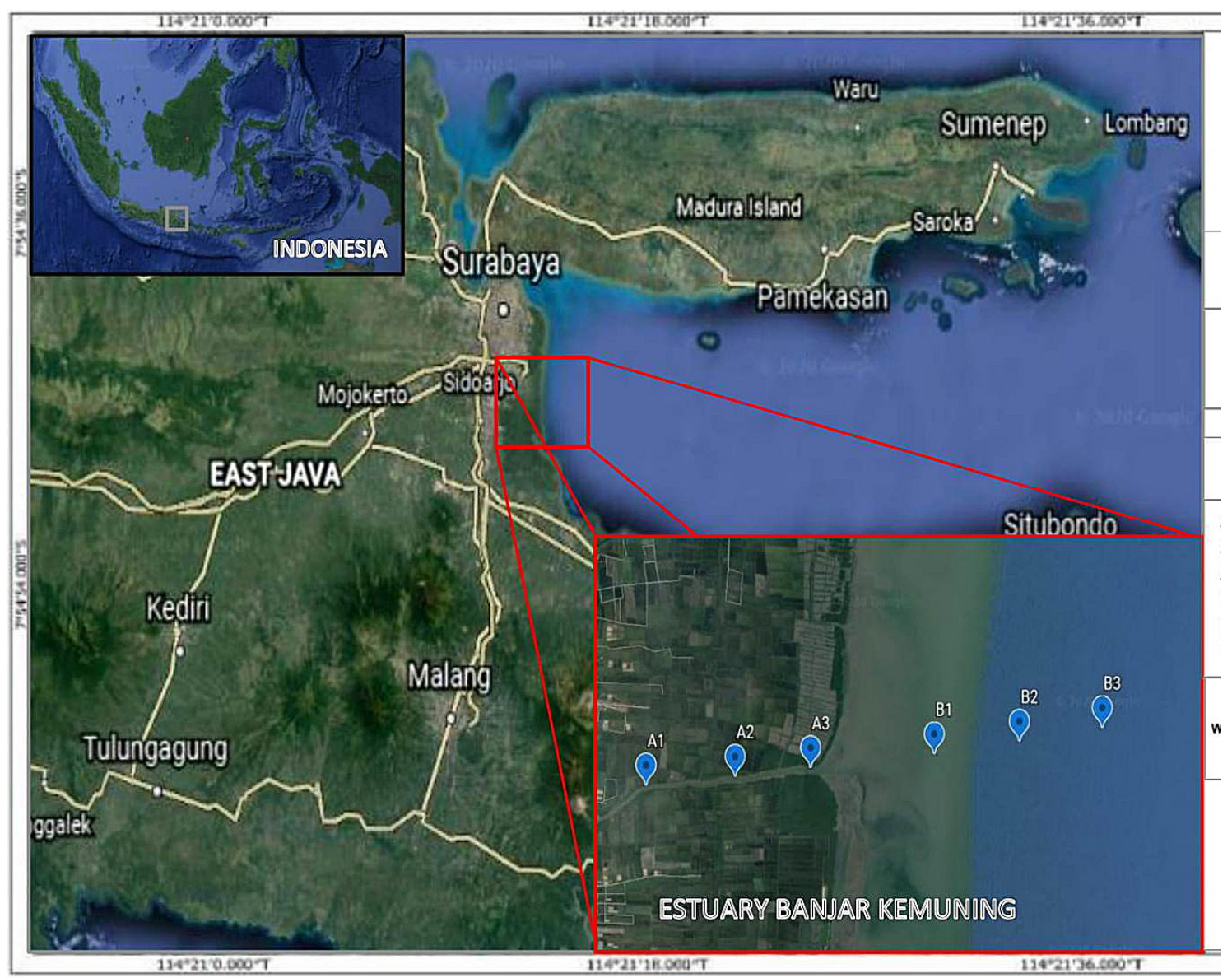

Figure 1. A map of sampling stations

identification was based on the books about phytoplankton identification including Phytoplankton Identification, Marine Phytoplankton Atlas of Kuwait's Waters and Identifying Marine Phytoplankton. The analysis of the phytoplankton abundance was conducted using Sedgewick rafter cell, with the APHA Standard Methods formula (2005).

\section{RESULTS AND DISCUSSION}

The abundance of phytoplankton based on Duncan's multiple range test shows that in October and November there is no significant difference, but there is a significant difference in December (Table 1). The highest average of phytoplankton abundance occurs in December and the lowest occurs in November. The lowest phytoplankton abundance is in zone B of 18,868 cells/L, while the highest phytoplankton abundance is in zone B of 22,754 cells/L. The estuary of Banjar Kemuning River in the dry season tends to be more stable than in the rainy season, which results in a lower phytoplankton abundance. According to Suryono \& Moersidik (2015), in the dry season, the river is more stable because it does not carry much sediment so that the deposition by the sediment is relatively lower. The high abundance of diatoms in zone $\mathrm{A}$ is due to the fact that this zone is an estuary that is affected by human activities, while zone $\mathrm{B}$ is the border area between the estuary and the open area.

Table 1. The results of ANOVA analysis on the average of phytoplankton abundance and chlorophyll-a during the study

\begin{tabular}{|l|c|c|}
\hline \multicolumn{1}{|c|}{ Month } & The average of phytoplankton abundance \pm STD & The average of chlorophyll-a content \pm STD \\
\hline October & $19,256 \pm 727^{\mathrm{b}}$ & $0.958 \pm 0.078^{\mathrm{b}}$ \\
\hline November & $19,044 \pm 411^{\mathrm{b}}$ & $0.998 \pm 0.039^{\mathrm{b}}$ \\
\hline December & $22,613 \pm 514^{\mathrm{a}}$ & $1.167 \pm 0.049^{\mathrm{a}}$ \\
\hline Mean and Standard Deviation & $20,293 \pm 1747$ & $1.041 \pm 0.108$ \\
\hline
\end{tabular}


The results of the analysis on the chlorophylla content showed that the temporal changes give a significantly different result to the changes in the chlorophyll-a content. The chlorophyll-a content based on Duncan's multiple range test showed that in October and November there is no significant difference, but there is a significant difference in December (Table 1).

The highest average of the chlorophyll-a content test occurs in December and the lowest occurs in October. This is in line with Lutzu's statement (2011) that the environmental factors that influence the process of the chlorophyll-a formation are the differences in light intensity and nutrients. The lowest chlorophyll-a content is found in zone $\mathrm{B}$ in October of $0.922 \mu \mathrm{g} / \mathrm{L}$. Meanwhile, the highest chlorophyll-a content occurs in December in zone A of $1.195 \mu \mathrm{g} / \mathrm{L}$, which is presumably because the influence of nutrient sources in the estuary decreases during the dry season.

The results of the regression calculation of the relationship between the value of phytoplankton abundance and chlorophyll-a content during the study from October to December 2019 show that $\left(\mathrm{R}^{2}\right)$, which is the coefficient of determination, is 0.840 , which means that the contribution of variable X (chlorophyll-a) to variable Y (phytoplankton abundance) is $84 \%$, while the remaining $16 \%$ is influenced by other factors. Other factors that can affect the diatom abundance are the changes in nutrients and light (Rahayu, 2019) and the dynamics of water movement (Sidabutar et al., 2016). The regression equation formed is $\mathrm{Y}=0.05+5.38 \mathrm{X}$. The positive sign $(+)$ indicates that if the phytoplankton abundance increases, the chlorophyll-a content increases as well see Figure 2.

In addition, the relationship between the phytoplankton abundance and the chlorophyll-a content is also indicated by the correlation coefficient (R) of 0.916, which means that the correlation is very strong $(0.75>R>0.99)$. The correlation results show a positive value, which means that the phytoplankton abundance generally increases the chlorophyll-a content in the waters.

The environmental factors that have a major effect on the phytoplankton abundance and the chlorophyll-a content in the estuary of Banjar Kemuning River are rainfall, temperature, dissolved oxygen, $\mathrm{pH}$, salinity, light intensity, turbidity, current, nitrate, and phosphate. The phytoplankton abundance in the waters can also change along with the environmental changes such as the rainy season which causes the waters to become unstable. According to Hoguane et al. (2012), high rainfall has an impact on the flow of nutrients in the sea which are carried by fresh water, so that it contains a high nutrient content. The high rainfall in December also affects the temperature in the waters.

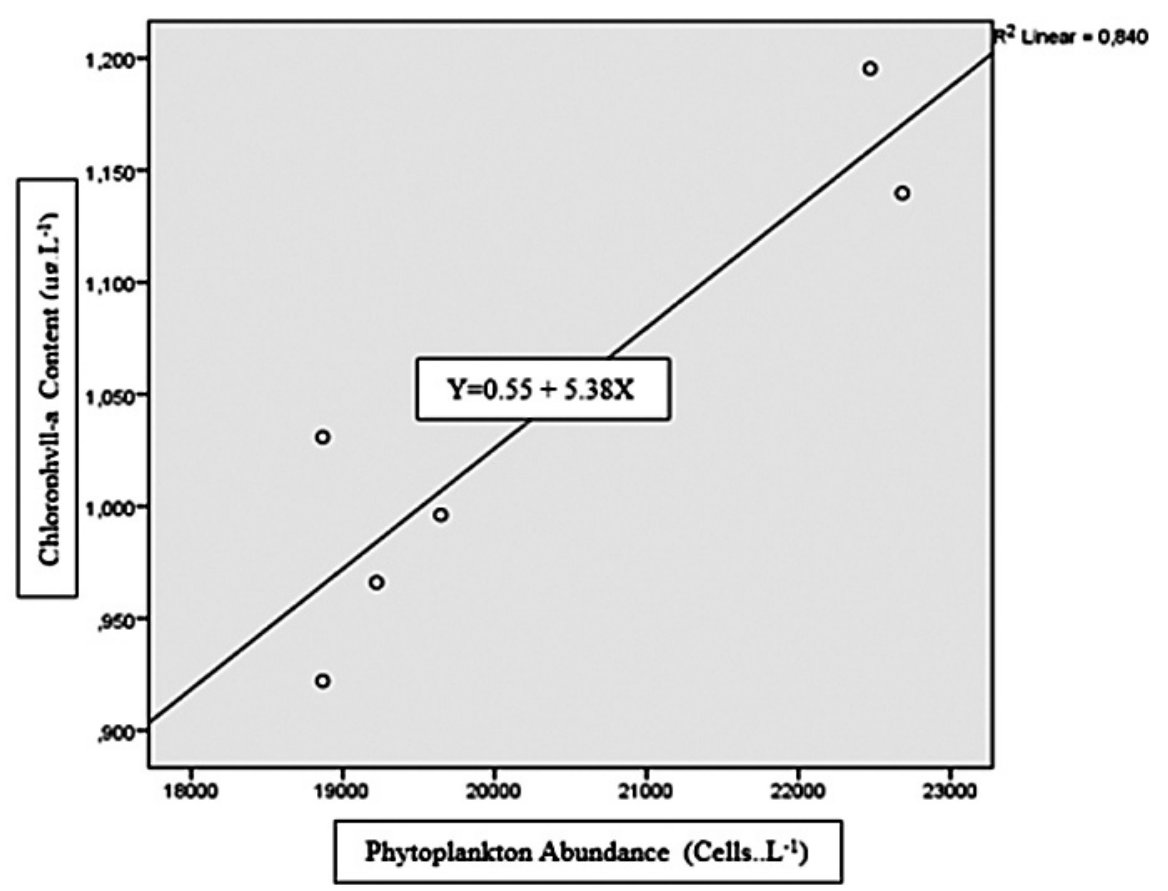

Figure 2. The graph of the linear regression on the relationship between phytoplankton abundance and chlorophyll-a content during the study in the estuary of Banjar Kemuning River 
According to Liwutang et al. (2013), generally phytoplankton can develop well at the temperatures of $20-30^{\circ} \mathrm{C}$ and can affect the distribution, composition and phytoplankton abundance in the waters. Temperature has an important role in the metabolism of aquatic organisms (Dwiardani et al., 2020; Damayanti et al., 2020; Holy et al., 2020). In general, the rate of phytoplankton photosynthesis will increase along with the water temperature, but it will decrease drastically after reaching a certain point. High temperature will increase the phytoplankton abundance as well as the chlorophyll-a content in it, while low temperature will reduce the phytoplankton abundance as well as the chlorophyll-a content.

Another influencing factor is light, because it is the main factor that supports phytoplankton to photosynthesize in the waters so that it greatly affects the growth of phytoplankton (Arsad et al., 2019; Anwar, 2015). The depth and turbidity of the waters will affect the penetration of sunlight intensity into the waters. The higher the turbidity, the greater the intensity of sunlight entering the waters (Nybakken, 1992). Light is a major factor in the process of photosynthesis. The light with sufficient intensity will increase the phytoplankton abundance and the chlorophyll-a content, while the light with lesser intensity will reduce it. This is in line with Faturohman et al.'s research (2016) stating that the high turbidity value at the $5^{\text {th }}$ station has a high abundance value. In this case, a high number of individuals and types of phytoplankton is found at the deep location compared to on the surface, due to the environmental factors such as the penetration of light entering the water, which is high enough to support the life of phytoplankton to a depth of \pm 4 meters.

Another contributing factor is the current which can be used as a medium for the availability of nutrients used to support the metabolism of phytoplankton and the life cycle through the movement of water mass due to tides (Arinardi et al., 1997; Szczykowska et al., 2015). In addition, currents also affect the phytoplankton abundance due to the current patterns that flow from rivers to the sea which contain a high number of nutrients such as nitrates and phosphates and are supported by high turbidity values (Widianingsih et al., 2007). The abundance of phytoplankton is associated with an increase in the nutrients entering coastal waters that are carried by currents from the estuaries (Pednekar et al., 2012).

The main factor in the phytoplankton abundance and the chlorophyll-a content is the nutrient content. This is because nutrients are a supporting factor that is needed by phytoplankton to grow, especially due to their nitrate and phosphate contents. According to Fachrul (2007), nitrates and phosphates are the nutrients that are important for the growth and metabolism of phytoplankton, constituting the indicators used to evaluate the quality and level of fertility in the waters. The content of nitrate and phosphate in marine waters will be higher if the depth increases than it is on the surface, because the nitrates and phosphates on the surface will be used more by phytoplankton (Fonny \& Hanif, 2011).

The results of the research show that in zone A in November the highest value of nitrate is $0.048 \mathrm{mg} / \mathrm{L}$, which still has a fairly low value compared to good nitrate values for phytoplankton growth, which is $0.9-3.5 \mathrm{mg} / \mathrm{L}$ (Sitompul et al, 2011). Meanwhile, the results of the study show that the highest phosphate level in zone A in December has a value of $1.934 \mathrm{mg} / \mathrm{L}$, while in zone B the highest phosphate value is in December of $0.854 \mathrm{mg} / \mathrm{L}$. These results showed a high value, because according to Sari (2005), the optimum phosphate content for phytoplankton growth ranges from $0.09-1.8 \mathrm{mg} / \mathrm{L}$. The importance of nutrient content in the waters is closely related to the phytoplankton abundance, where the higher the nutrient content in the waters, the higher the phytoplankton abundance and the chlorophylla content and vice versa.

\section{CONCLUSION}

On the basis of the results of the analysis pertaining to the phytoplankton abundance and the chlorophyll-a content in the estuary of Banjar Kemuning River, it was shown that there is a difference between the phytoplankton abundance and the chlorophyll-a content each month. The level of closeness of the relationship between the phytoplankton abundance and the chlorophyll-a content at the estuary of Banjar Kemuning River during the study was classified into high correlation, producing a linear regression equation $\mathrm{Y}=0.05+5.38 \mathrm{X}$. 


\section{Acknowledgements}

The authors are grateful for possibility to use the instrument laboratory and the funding from the Annual Work Plan Budget (RKAT) of the Faculty of Fisheries and Marine, Universitas Airlangga, Indonesia.

\section{REFERENCES}

1. American Public Health Association (APHA). 2005. Standard Methods for the Examination of Water and Wastewater, 21 th Edition. Washington: APHA, AWWA (American Waters Works Association) and WPCF (Water Pollution Control Federation), pages $3-42$.

2. Anwar A. 2015. Study of Abundance and Vertical Distribution of Phytoplankton in Kuricaddian Waters. Journal of Reverse Diwa, 6(2), 34-40.

3. Arief M., Laksmi L. 2006. Suitability Analysis of Pond Waters in Demak Regency in terms of Chlorophyll-a Value, Surface Water Temperature, and Suspended Solids Using Landsat ETM 7+ Satellite Image Data. Journal of Remote Sensing, 3(1), 108-118.

4. Arinardi O. H., Sutomo A. B., Yusuf S. A., Trimaningsih, E., Asnaryanti., Riyono S. H. 1997. Range of Abundance and Composition of Predominant Plankton in the Waters of Eastern Indonesia. Research and Development Center for Oceanography, Indonesian Institute of Sciences, Jakarta, iv + 137 pages.

5. Arsad S., Zsalzsabil N. A., Prasetiya F. S., Safitri I., Saputra D. K., Musa, M. 2019. Microalga Peryphyton Community on Different Substrates and Its Role as Aquatic Environmental Bioindicator. SAINTEK PERIKANAN: Indonesian Journal of Fisheries Science and Technology, 15(1), 73-79.

6. Azmi, K. A., Arsad, S., Sari, L. A. 2020. The Effect of Commercial Nutrients to Increase the Population of Skeletonema costatum on Laboratory and Mass Scales. IOP Conference Series: Earth and Environmental Science, 441(1), 012039.

7. Damayanti, K. Y., Mubarak, A. S., Sari, L. A. 2020. The Effect of Giving Fermented Rice Bran Suspension on Fecundity and Production of Moina macrocopa Off Spring Per Parent. IOP Conference Series: Earth and Environmental Science, 441(1), 012156.

8. Dwiardani, K. H., Sari, L. A., Sari, P. D. W., Nindarwi, D. D., Arsad, S. 2020. The Effect of Feed Larvae Chironomus sp. and High Pellet Protein to Seedling Goldfish (Carassius auratus). IOP Conference Series: Earth and Environmental Science. 441(1), 012015.

9. Fachrul, M. F. 2007. Composition and Modern Abundance of Phytoplankton in Ciliwung River Waters, Jakarta. Journal of Biodiversity, 9(4), 32-39.
10. Faturohman, I., Sunarto., Nurruhwati, I. 2016. Correlation of Plankton Abundance with Sea Water Temperature around PLTU Cirebon. Journal of Marine Fisheries, 7(1), 115-122.

11. Foony, J., Hanif, B. 2011. Study of Phosphate, Nitrate and Silicate Nutrients in the Waters of the Matasiri Islands, South Kalimantan. Journal of Marine Science, 16(3), 135-142.

12. Hoguane, A. M., Ezidio, D. L. C., Gammelsrød, T. 2012. Influence of Rainfall on Tropical Coastal Artisanal Fisheries A Case Study of Northern Mozambique. Journal of Integrated Coastal Zone Management, 12(4), 477-482.

13. Holy, N. H., Sari, L. A. 2020. The Effect of Catfish and Chicken Cultivation Waste to Daphnia sp. Culture. IOP Conference Series: Earth and Environmental Science, 441(1), 012057.

14. Larasati, A. S. A. 2017. Aquatic Productivity in Mangrove Ecosystems in Probolinggo, Situbondo and Banyuwangi in terms of Chlorophyll-a Phytoplankton Content. Thesis. Aquaculture Study Program. Faculty of Fisheries and Marine Affairs. Airlangga University, 75 pages.

15. Liwutang, Y. E., Manginsela, F. B., Tamanampo, J. F. W. S. 2013. The density and diversity of phytoplankton in the waters around the Manado Beach reclamation area. Journal of Platax Scientific, 1(3), 109-117.

16. Liyana, S. H., Sari, L. A., Dewi, N. N., Masithah, E. D., Sahidu, A. M and Pursetyo, K. T. 2019. Distribution Patterns and the Biomass of Bivalves at Segoro Tambak Estuary, Sedati, Sidoarjo, East Java. IOP Conference Series: Earth and Environmental Science, 236(1), 012043.

17. Lutzu, G. A. 2011. Analysis of the Growth of Microalgae in Batch and Semi-batch Photobioreactors. International Ph.D. Program in Environmental Sciences and Engineering. Università Degli Studi in Cagliari, 72 pages.

18. Magumba, D., Maruyama, A., Takagaki, M., Kato, A., Kikuchi, M. 2013. Relationships between Chlorophyll-a, Phosphorus and Nitrogen as Fundamentals for Controlling Phytoplankton Biomass in Lakes. Environmental Control Biology, 51(4), 179-185.

19. Marlian, N. 2016. Analysis of the Horizontal Distribution of Chlorophyll-a as an Indicator of Water Fertility Levels in Meulaboh Bay, Aceh Barat. Postgraduate School. Institut Pertanian Bogor, Bogor, 81 pages.

20. Masithah, E. D., Octaviana, Y. D., Manan, A. 2016. Effect of Probiotic Differences on C: N and N: P Ratios of Biofloc Culture Media in Experiment Tub. Journal of Aquaculture and Fish Health, 5(3), 118-125.

21. Mellard, J. P., Yoshiyama, K., Litchman, E., Klausmeier, C. A. 2011. The Vertical Distribution of Phytoplankton In Stratified Water Columns. Journal of 
Theoritical Biology, 26(1), 16-30.

22. Nindarwi, D. D., Sari, L. A., Wulansari, P. D., Samara, S. H., Santanumurti, M. B. 2020. Use of Hydrogen Peroxide to Improve Potential Redox Land Preparation of Land Towards Increasing Production of Traditional Shrimp Vanname (Litopeaneus vanname) in Wringin Putih, Muncar, Banyuwangi. IOP Conference Series: Earth and Environmental Science, 441(1), 012014.

23. Nybakken, J. W. 1992. Marine Biology. An Ecological Approach. Translation of Marine Biology: An Ecological Approach. Interpreters: M. Eidman, Koesoebiono, D.G. Bengen and M. Hutomo. Gramedia, Jakarta, 459 pages.

24. Pednekar, S. M., Matondkar, S. G. P., Kerkar, V. 2012. Spatiotemporal Distribution of Harmful Alga Flora in the Tropical Estuarine Complex of Goa India. Journal of The Scienctific World, 1(4), 1-11.

25. Pratama, N. A., Rahardja, B. S., Sari, L. A. 2020 The effect of Density as Skeletonema costatum Bioremediation Agent of Copper $(\mathrm{Cu})$ Heavy Metal Concentration. IOP Conference Series: Earth and Environmental Science, 441(1), 012029.

26. Pratiwi, E. D., Koenawan, C. J., Zulfikar, A. 2015. The Relationship between Plankton Abundance and Water Quality in Malang Waters, Bintan Regency Meeting, Riau Islands Province. (unpublished). Faculty of Marine and Fisheries Sciences. UMRAH, Riau, 14 pages.

27. Putri, A. D. A., Tjahjaningsih, W. 2018. PostHarvest Management of Porphyridium cruentum Microalgae Cultures at the Laboratory Scale and Intermediate Scale at the Center for Brackish Water Cultivation Fisheries, Jepara, Central Java. Journal of Aquaculture and Fish Health, 7(3), 111-117.

28. Rahayu, S. M. 2019. Spatial and Temporal Dynamics of Diatom Community (Bacillariophyceae) in Jakarta Bay Waters. Thesis. Aquatic Resources Management Study Program. Pasca Sarjana Institut Pertanian Bogor, Bogor. Pages 33.

29. Rinawati, M., Sari, L. A., Pursetyo, K. T. 2020. Chlorophyll and Carotenoids Analysis Spectrophotometer Using Method on Microalgae. IOP Conference Series: Earth and Environmental Science, 441(1), 012056.

30. Sari L. A., Sari, P. D. W., Nindarwi, D. D., Arsad, S., Affandi, M. 2019a. Harmful Algae Identification in Bomo Water Environment, Banyuwangi, East Java, Indonesia. Ecology, Environment and Conservation 25 (July Suppl. Issue) : S26-S31.

31. Sari, L. 2005. Study of Waters Saprobitas as a Management Basis for Kaligarang Watershed - Semarang. Thesis. Program Pasca Sarjana Magister Manajemen Sumberdaya Pantai. Universitas Diponegoro. Semarang.

32. Sari, L. A., Masithah, E. D. and Alamsjah, M. A. 2018b. The Effectivety of Carotenoid Spirulina platensis Which is Produced in Culture Media From
Ketchup Waste As An Antioxidant. Journal of Fisheries and Marine Research, 2(1), 9-14.

33. Sari, L. A., Pursetyo, K. T., Arsad, S., Masithah, E. D., Setiawan, E., Affandi, M. 2019b. The Effect of Nutrient Abundance on Distribution of Cyanobacteria and Chlorophyll-a in Sedati Water, Sidoarjo. Pollution Research 38 (August Suppl. Issue) : S27-S32.

34. Sari, L. A., Satyantini, W. H., Manan, A., Pursetyo, K. T., Dewi, N. N. 2018a. The Identification of Plankton Tropical Status in the Wonokromo, Dadapan and Juanda Extreme Water Estuary. IOP Conference Series: Earth and Environmental Science, 137(1), 012029.

35. Sidabutar, T., Bengen, D. G., Wouthuyzen, S., Partono, T. 2016. The Abundance of Phytoplankon and its Relationship to the N/P Ratio in Jakarta Bay, Indonesia. Journal of Biological Diversity, 17(2), 673-678.

36. Sitompul, N., Asmika, H., Madju, S. 2011. Phosphate Vertical Profile in Bandar Kayangan Lembah Sari Reservoir, Lembah Sari Village, Rumbai Pesisir District, Pekanbaru City. Journal of Aquatic, 2(1), 67-72.

37. Suprapto, D., Purnomo, P. W., Sulardiono, B. 2014. Analysis of Aquatic Fertility Based on the Physical Chemical Relationship of Basic Sediments with NO3-N and PO4-P at the Estuary of the Tuntang Demak River. Journal of Fisheries Science, 10(1), 56-61.

38. Suryono, D. D., Moersidik, S. S. 2015. Study of the Characteristics of the Ciliwung Estuary with the Nitrogen Budget Model. Journal of Humans and the Environment, 22(1), 32-38.

39. Syaifudin, M., Sulmartiwi, L., Andriyono, S. 2017. Addition of Red Microalgae Porphyridium cruentum to the Feed Against Color Brightness of Betta Fish (Betta splendens). Journal of Aquaculture and Fish Health, 6(1), 41-47.

40. Szczykowska, J., Siemieniuk, A., Wiater, J. 2015. Agricultural pollution and water quality in small retention reservoir in Korycin. Journal of Ecological Engineering, 16(1),141-146

41. Vonshak, A. 1997. Spirulina platensis (Arthrospira) : Physiology Cellbiology and Biotechnology Taylor and Francis. London, Pages 214.

42. Wenno L. F. 2007. Biodiversity of Planktonic Organisms in Relation to Water Quality and Water Mass Circulation in the Makassar Strait. Oceanographic Research Center (LIPI), 5(1), 34-39.

43. Widianingsih, R., Hartati, A., Djamali., Sugestiningsih. 2007. Abundance and Horizontal Distribution of Phytoplankton in the Waters of the East Coast of Belitung Island. Journal of Marine Science, 12(1), 6-11.

44. Widyorini, N. 2009. Pattern of Phytoplankton Community Structure Based on Pigment Content in Jepara Beach. Journal of Fisheries Science, 4(2), 69-75. 